\title{
Systematically describing gross lesions in corals
}

\author{
Thierry M. Work ${ }^{1,2,3, *}$, Greta S. Aeby ${ }^{2,3}$ \\ ${ }^{1}$ US Geological Survey, National Wildlife Health Center, Honolulu Field Station, 300 Ala Moana Boulevard, \\ Room 5-231, Honolulu, Hawaii 96850, USA \\ ${ }^{2}$ Hawaii Institute of Marine Biology, University of Hawaii, PO Box 1346, Kaneohe, Hawaii 96744, USA \\ ${ }^{3}$ Coral Disease \& Health Consortium, Hollings Marine Laboratory, 331 Fort Johnson Road, Charleston, \\ South Carolina 29412, USA
}

\begin{abstract}
Many coral diseases are characterized based on gross descriptions and, given the lack or difficulty of applying existing laboratory tools to understanding causes of coral diseases, most new diseases will continued to be described based on appearance in the field. Unfortunately, many existing descriptions of coral disease are ambiguous or open to subjective interpretation, making comparisons between oceans problematic. One reason for this is that the process of describing lesions is often confused with that of assigning causality for the lesion. However, causality is usually something not obtained in the field and requires additional laboratory tests. Because a concise and objective morphologic description provides the foundation for a case definition of any disease, there is a need for a consistent and standardized process to describe lesions of corals that focuses on morphology. We provide a framework to systematically describe and name diseases in corals involving 4 steps: (1) naming the disease, (2) describing the lesion, (3) formulating a morphologic diagnosis and (4) formulating an etiologic diagnosis. This process focuses field investigators on describing what they see and separates the process of describing a lesion from that of inferring causality, the latter being more appropriately done using laboratory techniques.
\end{abstract}

KEY WORDS: Pathology $\cdot$ Coral $\cdot$ Lesion $\cdot$ Nomenclature $\cdot$ Disease $\cdot$ Morphology $\cdot$ Diagnosis Resale or republication not permitted without written consent of the publisher

\section{INTRODUCTION}

Since the first reports in the early 1970s, there has been a steady increase in documentations of diseases in corals, particularly in the western tropical Atlantic Ocean (Green \& Bruckner 2000, Jordan-Dahlgren et al. 2004, Sutherland et al. 2004, Ward \& Lafferty 2004, Weil 2004) and also globally (Loya 2004, McClanahan 2004, Willis et al. 2004, Aeby 2005). Many of these diseases have been described only on a gross level, with less effort made in applying standard biomedical tools to determine their cause. Some exceptions to this include black-band disease in the Caribbean (Richardson 2004) and Vibrio-associated bleaching in the Mediterranean and Red Sea (Kushmaro et al. 2001, Rosenberg 2004), both of which have been extensively characterized at the levels of gross and microscopic morphology, pathophysiology, and etiopathogenesis.
The study of disease in corals also has suffered from a lack of standardization in nomenclature of gross lesions. Many existing descriptions of coral disease are ambiguous or open to subjective interpretation, making geographic comparisons (particularly between oceans) problematic. The major reason for this ambiguity is that many attempts to name diseases in corals have failed to uncouple the process of describing the lesion from inferring causality. Separation between those who study the biology of corals and those who study causes of animal diseases has also not been helpful. Because the description of many coral diseases will not, in the near future, progress beyond gross morphologic descriptions, there is a critical need for a systematic approach to describing lesions in corals such that a description in one geographic area can be applied similarly in another. The aim of this paper is to provide a structured approach to describ- 
ing gross lesions in corals and attempt to bridge the gap between coral biology and veterinary pathology.

\section{TERMINOLOGY}

Disease is any deviation or alteration from the normal structure or function of any body part or organ manifested by a characteristic set of clinical signs of known or unknown cause (Dorland 1982). Critical to the definition of disease is that causality (or etiology) is not necessarily inferred. Syndrome is a complex of clinical signs and is essentially synonymous with disease (Dorland 1982). Infectious causes of disease are those that are due to transmissible agents such as viruses, bacteria or parasites. Non-infectious causes of disease are due to non-transmissible agents and include things like trauma, toxins or toxicants. A lesion is any functional and morphologic change in tissues during disease, pathology is the study of lesions, and pathogenesis is the sequence of events from initiation of a lesion through its entire development (Thompson 1978). The case definition (Cummings et al. 2001) is a plastic concept encompassing all the morphologic and laboratory data that define a particular disease. Case definitions can change as data are accrued. Case definitions can be simple for poorly characterized diseases (e.g. 'cough') or complex for well-known diseases (e.g. tuberculosis: 'Productive or non-productive cough accompanied by opacities in lung fields on Xray, gross evidence of abscesses in lungs or other organs, microscopic manifestation of chronic inflammation with presence of acid-fast positive bacteria characterized on culture as Mycobacterium tuberculosis or M. bovis').

In corals, as in other animals, lesions caused by disease manifest morphologically as alterations in color, shape, size, quantity or texture. A good morphologic description of the lesion at the gross, and preferably microscopic level, is the foundation for any case definition. Pathology provides a standardized language to describe the morphology of a lesion and has been successfully applied to describe disease in many species of animals. This process involves 4 steps: (1) naming the disease, (2) describing the lesion, (3) formulating a morphologic diagnosis and (4) formulating an etiologic diagnosis. The confusion in the existing nomenclature of disease in corals is because many prior attempts to name diseases have tried to encapsulate all 4 steps into one or focused on only the first step. Parsing out the process of naming coral diseases as outlined above provides an explicit and standardized method that focuses the observer on describing rather than inferring causality.

\section{SYSTEMATIC DESCRIPTION}

\section{Naming a disease}

To enable investigators to collect epizootiologic data, it is helpful to have a name representing the description of the lesion. To be most informative, names should ideally encapsulate the host, morphology, and cause of the disease. For corals, this is usually not possible because the cause of most diseases is unknown (Richardson 1998, Sutherland et al. 2004). The next most desirable option is for the name of the disease to most closely reflect the host and morphology of the lesion, for example 'Porites ulcerative disease' (Raymundo et al. 2003).

\section{Describing a lesion}

While there is no one right way to describe a lesion, the description should be explicit, concise, and provide applicable information on distribution, location on colony, edges, margins, shapes, relief, texture, color, size, and structures affected. Use of appropriate terminology aids brevity (Fig. 1, Tables 1 \& 2). Distribution of the lesion on the colony can be focal, multifocal, multifocal to coalescing or diffuse. Depending on the shape of the colony, location of the lesion on the colony can be recorded as central, peripheral, basal, medial or apical (Table 1). Edges of the lesion can be identified as distinct, indistinct or annular, for example a band of discoloration. Margins of the lesion can be characterized as serrated, undulating, smooth or serpiginous. Most shapes of lesions in coral can be described as circular, oblong, pyriform, cruciform, linear, lanceolate or irregular. For lesions that have a 3 dimensional structure, relief can be described as umbonate, bosselated, nodular, exophytic or fimbriated. Size of the lesion can be characterized as large, medium or small, although measurements, size ranges or size classes reduce subjective interpretations. Number of lesions can be described as small, moderate or large or actual counts provided. Color descriptions should be limited to basic
Table 1. Distribution of lesions ( $\mathrm{X}=$ present) on corals as a function of colony morphology

\begin{tabular}{|lcccccc|}
\hline \multirow{2}{*}{ Colony type } & \multicolumn{7}{c|}{ Distribution } \\
\cline { 2 - 6 } & \multicolumn{1}{c}{ Central } & Peripheral & Basal & Medial & \multirow{2}{*}{ Apical } \\
\hline Massive & $\mathrm{X}$ & $\mathrm{X}$ & $\mathrm{X}$ & $\mathrm{X}$ & $\mathrm{X}$ \\
Encrusting & $\mathrm{X}$ & $\mathrm{X}$ & & & \\
Laminar/explanate & $\mathrm{X}$ & $\mathrm{X}$ & & & \\
Corymbose & $\mathrm{X}$ & $\mathrm{X}$ & $\mathrm{X}$ & $\mathrm{X}$ & $\mathrm{X}$ \\
Branching/foliaceous/ & $\mathrm{X}$ & $\mathrm{X}$ & $\mathrm{X}$ & $\mathrm{X}$ & $\mathrm{X}$ \\
arborescent & $\mathrm{X}$ & $\mathrm{X}$ & & & \\
Free living & & & & & \\
\hline
\end{tabular}


colors such as white, black, tan, brown, red, green, orange, pink, purple, blue, yellow, with avoidance of obscure terms (e.g. taupe, ecru). Texture of lesions can be characterized as rugose or smooth. Whether some or all of these terms are used will depend on the lesion. The description of the lesion should focus on physical characteristics with avoidance, or minimal interpretation, of processes (e.g. algal overgrowth). If interpretation of processes is included in the description, it should be explicitly demarcated by parentheses, for example, 'Bare intact skeleton with green hue (algae)'. A good description should immediately conjure to the reader's mind what the writer is seeing with minimum room for subjective interpretation.

\section{Morphologic diagnosis}

The morphologic diagnosis crystallizes the description of the lesion into a concise summary and provides a convenient way of communicating the salient features of the lesion. The morphologic diagnosis has 6 components (or parts) including extent, time, distribution, lesion, location, and structure affected, each (ideally) consisting of 1 word (Table 2). The first part deals with the extent of the lesion; a useful guide is to estimate the surface area of coral occupied by the lesions, for example, mild for lesions occupying $<25 \%$ of the colony, moderate for those occupying 26 to $50 \%$ and severe for those occupying $>50 \%$. The description can also help to assign a term to the extent of the lesions, with small, moderate or large numbers of lesions translating to mild, moderate or severe. Location of the lesion on the colony will depend on colony morphology (Fig. 1, Table 1).

Terms to describe time refer to rapidity of onset of the lesion and commonly include, from shortest to longest, acute (hours to days), subacute (weeks) or chronic (months or years). Assessing the time course of many lesions in corals can be difficult, particularly since most coral-disease surveys incorporate only a single observation in time. Furthermore, many diseases in corals have not been monitored over time, thus precluding our understanding of the morphologic characteristics used to assess the pathogenesis of a lesion. Nevertheless, for some lesions, a time component can be inferred. For example, growth anomalies in corals probably arise over months or years, implying a chronic process Tissue loss can also be gauged on a temporal basis.
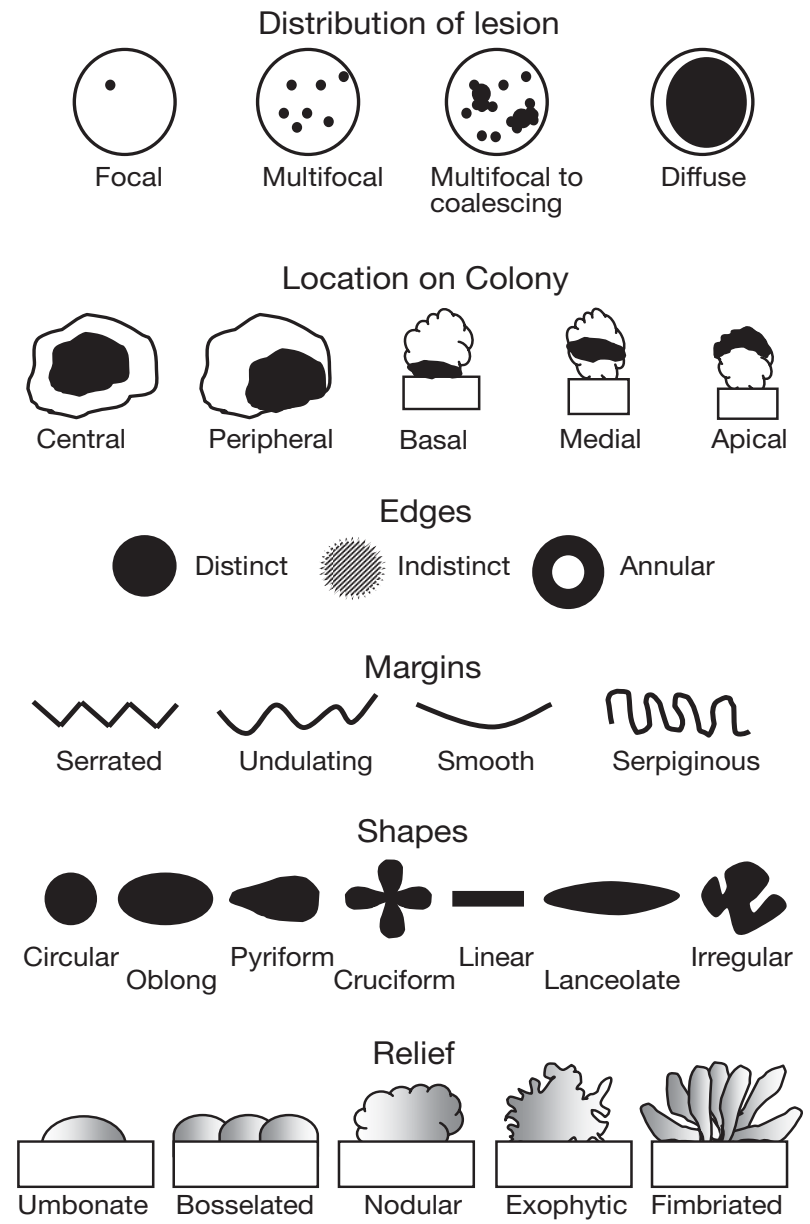

Fig. 1. Illustration of terms to describe distribution, location, edges, margins, shapes, and relief of lesions in corals

Table 2. Categories and terms used to describe a lesion (D) and make a morphologic diagnosis (M). Some terms apply to both description and morphologic diagnosis $(\mathrm{D}, \mathrm{M})$

\begin{tabular}{|c|c|c|}
\hline Category & Term & Application \\
\hline Distribution (Di) & $\begin{array}{l}\text { Focal, multifocal, multifocal } \\
\text { to coalescing, diffuse }\end{array}$ & $\mathrm{D}, \mathrm{M}$ \\
\hline Location (Lo) & $\begin{array}{l}\text { Basal, medial, apical, peripheral, } \\
\text { central, colony-wide }\end{array}$ & $\mathrm{D}, \mathrm{M}$ \\
\hline Edges (Ed) & Distinct, indistinct, annular & $\mathrm{D}$ \\
\hline Margins (Ma) & Serrated, undulating, smooth, serpiginous & $\mathrm{D}$ \\
\hline Shapes (Sh) & $\begin{array}{l}\text { Circular, oblong, pyriform, } \\
\text { cruciform, linear, lanceolate, irregular. }\end{array}$ & $\mathrm{D}$ \\
\hline Relief (Re) & Umbonate, bosselated, nodular, exophytic & $\mathrm{D}$ \\
\hline Size (Si) & Small, medium, large, actual measurement & $\mathrm{D}$ \\
\hline Number (Nu) & Small, medium, large, actual count & $\mathrm{D}$ \\
\hline Color (Co) & $\begin{array}{l}\text { White, black, tan, brown, red, green, } \\
\text { orange, pink, purple, blue, yellow }\end{array}$ & $\mathrm{D}$ \\
\hline Texture (Te) & Rugose, smooth. & $\mathrm{D}$ \\
\hline Extent (Ex) & $\begin{array}{l}\text { Mild }(1-20 \%), \text { moderate }(21-50 \%) \text {, } \\
\text { severe }(51-100 \%)\end{array}$ & M \\
\hline Time (Ti) & Acute, subacute, chronic & M \\
\hline Lesion (Le) & Tissue loss, discoloration, growth anomaly & $\mathrm{D}, \mathrm{M}$ \\
\hline $\begin{array}{l}\text { Structures } \\
\text { affected (St) }\end{array}$ & Polyp, coenosarc, skeleton & $\mathrm{D}, \mathrm{M}$ \\
\hline
\end{tabular}


If no algae are present on tissue-denuded skeleton, an acute process can be inferred. Algae will colonize bare skeleton in several days to 1 wk giving it a green or brown hue, thus indicating a subacute process. Combinations of the terms can also be employed. For example, tissue loss, revealing skeleton covered by algae and separated from intact tissue by a band of bare white skeleton (indicating rapid tissue loss in the margins) could be characterized as acute to subacute. Lesions in corals can be unambiguously categorized as tissue loss, growth anomaly, or discoloration (Work \& Rameyer 2005). Structures affected include polyps, coenosarc or skeleton. Table 2 summarizes the terminology suggested for describing lesions and formulating a morphologic diagnosis.

\section{Etiologic diagnosis}

The etiologic diagnosis describes the cause (etiology) of the lesion. Except for rare cases (Aeby 1998), determining what causes a particular lesion in a coral will require laboratory investigations, particularly in cases where microbes, toxins or toxicants are suspected. However, cause can at times be deduced in the field, particularly when tissue loss is seen in the pres- ence of a predator. Thus, when acute tissue loss is seen in corals, it is helpful to examine the immediate surroundings for possible predators (snails, starfish, fishes). For example, Pocillopora sp. completely denuded of tissue in the presence of Acanthaster sp. (crown-of-thorns starfish) would merit the etiologic diagnosis 'Acanthaster predation'. Similarly, distinct circular-to-oblong erosions of skeleton and tissue with evidence of parrotfish feeding on coral would merit the diagnosis 'Parrotfish predation'. Evidence of pink nodules on Porites sp. with microscopic evidence of trematode metacercaria would merit the etiologic diagnosis 'Trematodiasis'. Examples of diseases, descriptions, morphologic and etiologic diagnoses are given in Fig. 2, and Table 3 applies this system to some coral diseases described in literature (Sutherland et al. 2004).

The study of coral disease is its infancy, but has important ramifications for coral-reef conservation and health. When attempting to determine the relative importance of causes of disease in corals, it is useful to keep in mind the 2 categories of causality (infectious, non-infectious) and not assume that all diseases are due to infectious processes. Much progress has been made in increasing awareness of the significance of the problem and in documenting degradation of reefs
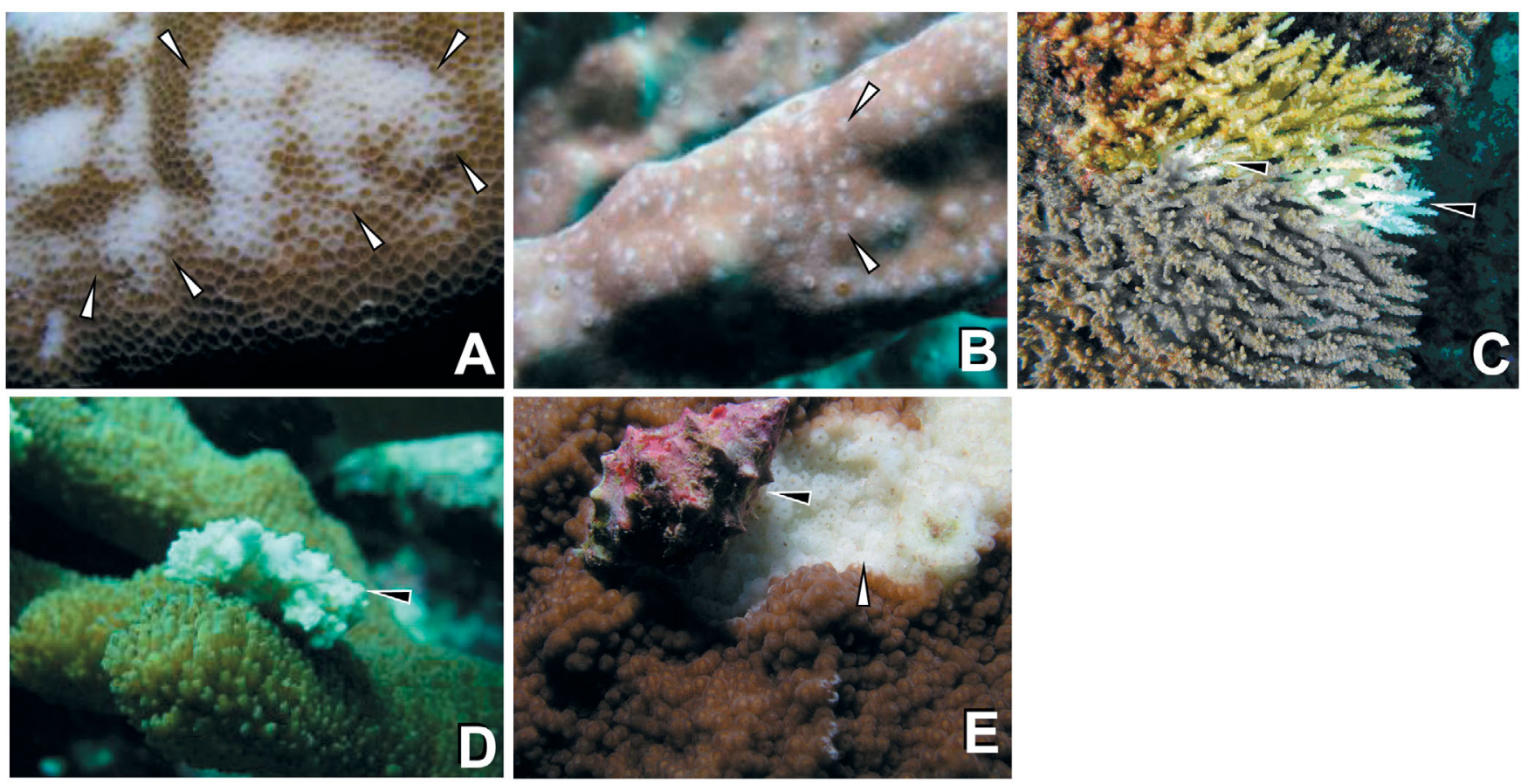

Fig. 2. (A) Goniastrea bleaching (Goniastrea sp.); note areas of white tissue discoloration with undulating to serpiginous margins (white arrows). (B) Millepora multifocal tissue loss (Millepora sp.); note distinct foci of tissue loss (white arrows). (C) Acropora white syndrome (Acropora cytherea); note band of bare white skeleton (black arrows) separating intact tissue (bottom) from algae covered skeleton (top). (D) Acropora skeletal growth anomaly (Acropora abrotenoides); note exophytic skeletal growth overlaid by white tissue bereft of polyps (black arrow). (E) Montipora snail predation (Montipora sp.); note distinct linear area of tissue loss (white arrow) accompanied by presence of marine snail (black arrow) 
Table 3. Name, description, and morphologic and etiologic diagnosis of selected coral diseases described in the literature for the Caribbean and Indo-Pacific. For Caribbean diseases, figure references apply to study of Sutherland et al. (2004); for Indo-Pacific corals, figure references apply to Fig. 2 of present study. Abbreviations (in parentheses) as in Table 2. Etiologic diagnosis: great caution is advised when assigning an etiologic diagnosis based on appearance of gross lesions alone in absence of supporting evidence, particularly when microbes, toxins, or toxicants are suspected as a cause. Given the limited host response repertoire of corals, it is likely that, in certain cases, different causal agents will elicit similar gross lesions

\begin{tabular}{|c|c|c|c|c|}
\hline Name & Description & Morphologic diagnosis & Etiologic diagnosis & Fig. ref. \\
\hline \multicolumn{5}{|l|}{ Caribbean } \\
\hline Black band & $\begin{array}{l}\text { Diffuse (Di), centrally to peripherally situated } \\
\text { (Lo), large (Si), irregular (Sh), distinct (Ed) area } \\
\text { of tissue loss revealing intact bare skeleton (Le) } \\
\text { separated from normal tissue by non-uniform } \\
\text { thin black (Co) undulating annular border (Ma), } \\
\text { and with central, irregular (Sh), indistinct, (Ed) } \\
\text { green to brown (Co) area (algae) }\end{array}$ & $\begin{array}{l}\text { Severe (Ex), central to eccentric } \\
\text { (Lo), diffuse (Di), acute to sub- } \\
\text { acute (Ti) tissue loss, with intact } \\
\text { skeleton and black annular } \\
\text { margin (Le), polyp, coenosarc (St) }\end{array}$ & $\begin{array}{l}\text { Microbial consortium } \\
\text { with cyanobacteria }\end{array}$ & $3 a$ \\
\hline $\begin{array}{l}\text { White plague, } \\
\text { Type II }\end{array}$ & $\begin{array}{l}\text { Diffuse (Di), peripherally and basally situated } \\
\text { (Lo), large (Si), irregular (Sh), distinct (Ed), area } \\
\text { of tissue loss revealing intact bare white } \\
\text { skeleton (Le) }\end{array}$ & $\begin{array}{l}\text { Severe }(\mathrm{Ex}) \text {, basal to peripheral } \\
(\mathrm{Lo}) \text {, diffuse }(\mathrm{Di}) \text {, acute }(\mathrm{Ti}) \text { tissue } \\
\text { loss }(\mathrm{Le}), \text { polyp, coenosarc }(\mathrm{St})\end{array}$ & Aurantimoniasis & $3 b$ \\
\hline Aspergillosis & $\begin{array}{l}\text { Large numbers }(\mathrm{Nu}) \text { of multifocal to coalescing } \\
\text { (Di), centrally situated (Lo), small to large (Si), } \\
\text { distinct (Ed), irregular (Sh) areas of tissue loss, } \\
\text { (Le) revealing gorgonin covered by amorphous } \\
\text { grey-green (Co) material (turf algae) and } \\
\text { bordered by broad diffuse (Di), distinct (Ed), } \\
\text { irregular (Sh) undulating (Ma) border of } \\
\text { purple (Co) discoloration }\end{array}$ & $\begin{array}{l}\text { Severe (Ex), central (Lo), multi- } \\
\text { focal (Di), chronic (Ti) tissue loss } \\
\text { with discoloration (Le), polyp, } \\
\text { coenosarc (St) }\end{array}$ & Aspergillosis & $3 e$ \\
\hline $\begin{array}{l}\text { White band, } \\
\text { Type I }\end{array}$ & $\begin{array}{l}\text { Diffuse (Di), basally situated (Lo), large (Si), dis- } \\
\text { tinct (Ed) areas of tissue loss, revealing wide } \\
\text { band of intact, bare skeleton (Le) that is well- } \\
\text { differentiated from more distal skeleton and } \\
\text { discolored tan to brown (Co) (algae) }\end{array}$ & $\begin{array}{l}\text { Severe }(\mathrm{Ex}), \text { basal }(\mathrm{Lo}) \text {, diffuse } \\
(\mathrm{Di}), \text { subacute }(\mathrm{Ti}) \text { tissue loss (Le), } \\
\text { polyp, coenosarc (St) }\end{array}$ & None & $3 f$ \\
\hline $\begin{array}{l}\text { White pox } \\
\text { disease }\end{array}$ & $\begin{array}{l}\text { Small numbers }(\mathrm{Nu}) \text { of multifocal }(\mathrm{Di}), \text { basal to } \\
\text { apically distributed (Lo), small to medium }(\mathrm{Si}) \text {, } \\
\text { distinct (Ed), circular, oblong or pyriform (Sh) } \\
\text { areas of tissue loss revealing intact bare white } \\
\text { skeleton (Le) }\end{array}$ & $\begin{array}{l}\text { Mild (Ex), basal to apical (Lo), } \\
\text { multifocal (Di), acute (Ti) tissue } \\
\text { loss (Le), polyp, coenosarc (St) }\end{array}$ & Serratiosis & $4 a$ \\
\hline Yellow blotch & $\begin{array}{l}\text { Diffuse (Di), centrally situated (Lo), large (Si), } \\
\text { circular to oblong (Sh), distinct (Ed) area of tissue } \\
\text { loss revealing intact bare white skeleton (Le) }\end{array}$ & $\begin{array}{l}\text { Severe }(\mathrm{Ex}) \text {, central (Lo), diffuse } \\
\text { (Di), acute }(\mathrm{Ti}) \text { tissue loss (Le), } \\
\text { polyp, coenosarc (St) }\end{array}$ & None & $4 \mathrm{c}$ \\
\hline $\begin{array}{l}\text { Dark spot } \\
\text { disease }\end{array}$ & $\begin{array}{l}\text { Focal and diffuse (Di), mainly peripherally } \\
\text { situated (Di), distinct (Ed), small to large (Si) } \\
\text { areas of brown (Co) discoloration (Le) with indis- } \\
\text { tinct (Ed), undulating (Ma) borders accompanied } \\
\text { by focal irregular (Sh) areas of tissue loss overlaid } \\
\text { by deposits of amorphous grey flocculent } \\
\text { material (Le) (sediment) }\end{array}$ & $\begin{array}{l}\text { Severe (Ex), peripheral (Lo), } \\
\text { diffuse (Di) brown discoloration } \\
\text { with chronic (Ti) tissue loss (Le), } \\
\text { polyp, coenosarc (St) }\end{array}$ & None & $4 \mathrm{e}$ \\
\hline \multicolumn{5}{|l|}{ Indo-Pacific } \\
\hline $\begin{array}{l}\text { Goniastrea } \\
\text { bleaching }\end{array}$ & $\begin{array}{l}\text { Focal to diffuse (Di), large (Si), central to peri- } \\
\text { pheral (Lo), indistinct (Ed), irregular (Sh) areas } \\
\text { of white discoloration (Le) with indistinct undu- } \\
\text { lating to serpiginous (Ma) border encompassing } \\
\text { polyps and coenosarc (St) }\end{array}$ & $\begin{array}{l}\text { Severe }(\mathrm{Ex}) \text {, colony-wide (Lo), } \\
\text { diffuse }(\mathrm{Di}) \text {, acute to subacute } \\
\text { (Ti), white discoloration (Le), } \\
\text { polyps and coenosarc }(\mathrm{St})\end{array}$ & None & $2 \mathrm{~A}$ \\
\hline $\begin{array}{l}\text { Millepora } \\
\text { multifocal tissue } \\
\text { loss }\end{array}$ & $\begin{array}{l}\text { Numerous (Nu), colony-wide (Lo), small (Si) } \\
\sim 1 \text { to } 3 \mathrm{~mm} \text {, multifocal to coalescing (Di), distinct } \\
\text { (Ed), circular to oblong (Sh), areas of tissue loss } \\
\text { (Le) encompassing polyps and coenosarc (St) }\end{array}$ & $\begin{array}{l}\text { Severe }(\mathrm{Ex}) \text {, colony-wide (Lo), } \\
\text { multifocal to coalescing (Di) } \\
\text { tissue loss (Ti), polyps, and } \\
\text { coenosarc (St) }\end{array}$ & None & $2 B$ \\
\hline
\end{tabular}


Table 3 (continued)

\begin{tabular}{|c|c|c|c|c|}
\hline Name & Description & Morphologic diagnosis & Etiologic diagnosis & Fig. ref. \\
\hline $\begin{array}{l}\text { Acropora white } \\
\text { syndrome }\end{array}$ & $\begin{array}{l}\text { Large }(\mathrm{Si}) \text {, diffuse }(\mathrm{Di}) \text {, oblong area of tissue loss } \\
\text { revealing intact, green (Co) (algae covered) ske- } \\
\text { leton (Le), distinctly (Ed) separated from intact } \\
\text { tissue by } 2 \text { to } 3 \mathrm{~cm} \text { band of intact, white, bare } \\
\text { skeleton (Le) }\end{array}$ & $\begin{array}{l}\text { Severe }(\mathrm{Ex}) \text {, central (Lo), diffuse } \\
(\mathrm{Di}) \text {, acute to subacute }(\mathrm{Ti}) \text { tissue } \\
\text { loss (Le), polyps and coenosarc (St) }\end{array}$ & None & $2 \mathrm{C}$ \\
\hline $\begin{array}{l}\text { Acropora growth } \\
\text { anomaly }\end{array}$ & $\begin{array}{l}\text { Focal (Di), apical (Lo), small }(\sim 5 \times 5 \times 4) \mathrm{cm}(\mathrm{Si}) \text {, } \\
\text { distinct }(\mathrm{Ed}) \text {, exophytic skeletal growth overlaid } \\
\text { by white tissue bereft of polyps (Le) }\end{array}$ & $\begin{array}{l}\text { Mild (Ex), apical (Lo), focal (Di), } \\
\text { chronic (Ti), skeletal growth ano- } \\
\text { maly and white discoloration (Le), } \\
\text { aberrant to missing polyps (St) }\end{array}$ & None & $2 \mathrm{D}$ \\
\hline $\begin{array}{l}\text { Montipora snail } \\
\text { predation }\end{array}$ & $\begin{array}{l}\text { Peripheral (Lo), linear to meandering (Sh), dis- } \\
\text { tinct }(\mathrm{Ed}) \text { area of tissue loss occupying ca. } 10 \% \\
\text { of colony ( } \mathrm{Si} \text { ) and revealing bare, white, intact } \\
\text { skeleton (Le) with presence of snail }\end{array}$ & $\begin{array}{l}\text { Mild (Ex), peripheral (Lo), diffuse } \\
\text { (Di), acute (Ti),, tissue loss } \\
\text { associated with snail (Le), polyp } \\
\text { and coenosarc (St) }\end{array}$ & Snail predation & $2 \mathrm{E}$ \\
\hline
\end{tabular}

on a spatial scale. Employing the tools of diagnostic medicine to understand the pathogenesis and causes of disease will substantially aid our ability to address and manage diseases of coral. A good morphologic description will provide a solid foundation to that effort.

Acknowledgements. We are very grateful to Esther Peters, Lou Sileo, and Cheryl Woodley for constructive comments on earlier drafts of the manuscript.

\section{LITERATURE CITED}

Aeby GS (1998) A digenean metacercaria from the reef coral, Porites compressa, experimentally identified as Podocotyloides stenometra. J Parasitol 84:1259-1261

Aeby GS (2005) Outbreak of coral disease in the Northwestern Hawaiian Islands. Coral Reefs 24:481

Cummings SR, Browner WS, Grady D, Hearst N, Newman TB, Hulley SB (eds) (2001) Designing clinical research: an epidemiologic approach, Lippincott Williams \& Wilkins, Baltimore, MD

Dorland (1982) Dorland's pocket medical dictionary. WB Saunders, Philadelphia, PA

Green E, Bruckner A (2000) The significance of coral disease epizootiology for coral reef conservation. Biol Conserv 96:347-361

Jordan-Dahlgren E, Rodriguez-Martinez E (2004) Coral diseases in Gulf of Mexico reefs. In: Rosenberg E, Loya Y (eds) Coral health and disease. Springer-Verlag, Berlin, p 105-118

Kushmaro A, Banin E, Loya Y, Stackebrandt E, Rosenberg E (2001) Vibrio shiloi sp. nov. the causative agent of bleaching of the coral Oculina patagonica. Int J Syst Evol Microbiol 51:1383-1388

Editorial responsibility: Albert K. Sparks, Seattle, Washington, USA
Loya Y (2004) The coral reefs of Eilat-past, present and future: three decades of coral community structure studies. In: Rosenberg E, Loya Y (eds) Coral health and disease. Springer-Verlag, Berlin, p 1-68

McClanahan T (2004) Coral bleaching, diseases, and mortality in the western Indian Ocean. In: Rosenberg E, Loya Y (eds) Coral health and disease. Springer-Verlag, Berlin, p 157-176

Raymundo LJ, Harvell CD, Reynolds TL (2003) Porites ulcerative white spot disease: description, prevalence, and host range of a new coral disease affecting Indo-Pacific reefs. Dis Aquat Org 56:95-104

Richardson L (1998) Coral diseases: what is really known? Trends Evol Ecol 13:438-443

Richardson L (2004) Black band disease. In: Rosenberg E, Loya Y (eds) Coral health and disease. Springer-Verlag, Berlin, p 325-336

Rosenberg E (2004) The bacterial disease hypothesis of coral bleaching. In: Rosenberg E, Loya Y (eds) Coral health and disease. Springer-Verlag, Berlin, p 445-462

Sutherland K, Porter J, Torres C (2004) Disease and immunity in Caribbean and Indo-Pacific zooxanthellate corals. Mar Ecol Prog Ser 266:273-302

Thompson RG (1978) General veterinary pathology. WB Saunders, Philadelphia, PA

Ward JR, Lafferty KD (2004) The elusive baseline of marine disease: are diseases in ocean ecosystems increasing? PLOS Biol 2:542-547

Weil E (2004) Coral reef diseases in the wider Caribbean. In: Rosenberg E, Loya Y (eds) Coral health and disease. Springer-Verlag, Berlin, p 25-68

Willis BL, Page CA, Dinsdale EA (2004) Coral disease on the Great Barrier Reef. In: Rosenberg E, Loya Y (eds) Coral health and disease. Springer-Verlag, Berlin, p 69-104

Work TM, RA Rameyer (2005) Evaluating coral reef health in American Samoa. Coral Reefs 24:384-390

Submitted: October 30, 2005; Accepted: January 13, 2006

Proofs received from author(s): April 4, 2006 